\title{
Fat-free mass change after nutritional rehabilitation in weight losing COPD: role of insulin, C-reactive protein and tissue hypoxia
}

This article was published in the following Dove Press journal: International Journal of COPD

16 February 2010

Number of times this article has been viewed

\author{
Simonetta Baldi \\ Roberto Aquilani \\ Gian Domenico Pinna \\ Paolo Poggi \\ Angelo De Martini \\ Claudio Bruschi \\ Department of Pneumology and \\ Biomedical Engineering, Scientific \\ Institute of Montescano, Salvatore \\ Maugeri Foundation I.R.C.C.S. \\ Pavia, Italy
}

Background: Fat-free mass (FFM) depletion marks the imbalance between tissue protein synthesis and breakdown in chronic obstructive pulmonary disease (COPD). To date, the role of essential amino acid supplementation (EAAs) in FFM repletion has not been fully acknowledged. A pilot study was undertaken in patients attending pulmonary rehabilitation.

Methods: 28 COPD patients with dynamic weight loss $>5 \%$ over the last 6 months were randomized to receive EAAs embedded in a 12-week rehabilitation program (EAAs group $n=14$ ), or to the same program without supplementation (C group $n=14)$. Primary outcome measures were changes in body weight and FFM, using dual X-ray absorptiometry (DEXA).

Results: At the 12 th week, a body weight increment occurred in $92 \%$ and $15 \%$ of patients in the EAAs and $\mathrm{C}$ group, respectively, with an average increase of $3.8 \pm 2.6 \mathrm{~kg}(P=0.0002)$ and $-0.1 \pm 1.1 \mathrm{~kg}(P=0.81)$, respectively. A FFM increment occurred in $69 \%$ and $15 \%$ of EAAs and $C$ patients, respectively, with an average increase of $1.5 \pm 2.6 \mathrm{~kg}(P=0.05)$ and $-0.1 \pm 2.3 \mathrm{~kg}$ $(P=0.94)$, respectively. In the EAAs group, FFM change was significantly related to fasting insulin $\left(\mathrm{r}^{2} 0.68, P<0.0005\right)$, C-reactive protein $(\mathrm{C}-\mathrm{RP})\left(\mathrm{r}^{2}=0.46, P<0.01\right)$, and oxygen extraction tension $\left(\mathrm{PaO}_{2 \mathrm{x}}\right)\left(\mathrm{r}^{2}=0.46, P<0.01\right)$ at end of treatment. These three variables were highly correlated in both groups ( $\mathrm{r}>0.7, P<0.005$ in all tests).

Conclusions: Changes in FFM promoted by EAAs are related to cellular energy and tissue oxygen availability in depleted COPD. Insulin, C-RP, and $\mathrm{PaO}_{2 \mathrm{x}}$ must be regarded as clinical markers of an amino acid-stimulated signaling to FFM accretion.

Keywords: COPD, pulmonary rehabilitation, branched chain amino acids, insulin, systemic inflammation

\section{Introduction}

Cachexia, defined as weight loss with disproportional fat-free mass wasting, occurs in about one-third of patients with severe chronic obstructive pulmonary disease (COPD) eligible for pulmonary rehabilitation, ${ }^{1}$ and represents a cause of increased mortality independent of ventilatory limitation. ${ }^{2}$

Despite the fact that fat-free mass (FFM) depletion is recognized as a marker of the imbalance between tissue protein synthesis and breakdown in chronic wasting syndrome, there is insufficient knowledge about the determinants of the switch to catabolic intermediary metabolism during the course of the disease. Previous studies have documented a fall in muscle protein synthesis in depleted patients with emphysema, ${ }^{3}$ and a high protein turnover in post-absorptive state in stable COPD patients. ${ }^{4}$ Further studies ${ }^{5-8}$ have also indicated that an elevated inflammatory state has consequences for protein need and intermediary metabolism, putting forward the

submit your manuscript | www.dovepress.con 
idea that a hypoxic-mediated and cytokine-mediated wasting occurs in COPD patients, who involuntary lose weight.

These findings would entail making accretion or maintenance of FFM a rehabilitation strategy to amplify reconditioning effects of physical training and to improve physical performance in depleted COPD patients. As similar strategies are not fully acknowledged yet, future studies capable of either addressing the issue of prevention of pulmonary cachexia, or shedding light on its pathogenesis are advisable. Metabolic studies ${ }^{9}$ have documented that high physiologic concentrations of branched chain amino acids, particularly leucine, exert a bi-directional modulation on insulin signaling pathways that promote protein synthesis and gluconeogenesis, while impairing glucose transport and glycogen synthesis. To date the idea of a cross-talk between amino acid and insulin signaling to glucose and protein metabolism remains largely speculative in depleted COPD patients. Thus, the present study has two aims. First, to evaluate the change in body weight and FFM after an essential amino acid supplementation (EAAs) intervention embedded in a rehabilitation program in weight-losing COPD patients. Second, to explore the mechanisms that modulate FFM accretion in response to ingestion of amino acids (ie, the factors that control protein turnover in tissues). We hypothesized a relationship between the supposed anabolic response to EAAs, ie, the change in FFM, and fasting insulin plasma levels, C-reactive protein (C-RP), and tissue oxygen availability assessed by oxygen extraction tension $\left(\mathrm{PaO}_{2 \mathrm{x}}\right)$. The latter is a noninvasive measurement, which summarizes the degree of compensation among arterial oxygen tension, blood oxygen carrying capacity and affinity. ${ }^{10}$ In addition, the mutual interrelationships between insulin plasma levels, $\mathrm{C}-\mathrm{RP}$ and $\mathrm{PaO}_{2 \mathrm{x}}$ were investigated before and after 12 weeks of nutrition and/or rehabilitation interventions.

\section{Methods}

\section{Participants}

Twenty-eight patients with severe COPD according to American Thoracic Society (ATS) criteria, ${ }^{11}$ and experiencing a dynamic weight loss ( $>5 \%$ of body weight) over the previous 6 months were consecutively recruited at the start of an inpatient pulmonary rehabilitation program while clinically stable at the Pulmonary Rehabilitation Unit of S Maugeri Foundation I.R.C.C.S (Montescano-Italy). Exclusion criteria included: any malignancy, gastrointestinal disorders, severe endocrine disorders or recent surgery, recent (ie, within the last 4 weeks) respiratory tract infection, and abnormal fluid balance as manifested by the presence of edema or regular use of diuretics. The medical ethics committee of the Scientific Institute of Montescano approved the study design and a written informed consent was obtained prior to the study.

\section{Pulmonary rehabilitation}

All the eligible patients were randomly allocated to one of the following interventions: A) EAAs embedded in a 4-week inpatient rehabilitation program, followed by EAAs embedded in an 8-week outpatient rehabilitation program (2 sessions a day of 30 minutes unloaded bicycle training) (EAAs group), and B) a 4-week inpatient rehabilitation program, followed by an 8-week outpatient rehabilitation program ( 2 sessions a day of 30 minutes unloaded bicycle training) (C group). All measurements were performed during the first 5 days after admission to the hospital and in addition after $12 \pm 2$ weeks of intervention. The response to nutrition and/or rehabilitation interventions was evaluated as body weight change, and FFM change reached at the end of nutritional rehabilitation. The essential and nonessential amino acid mixture (Aminotrofic ${ }^{\circledR}$, Erre Kappa Euroterapici, Milan, Italy) contains high and balanced branched chain amino acid concentrations (see Table 1). The dosage was $4 \mathrm{~g}$, given twice a day, as two liquid supplements of $200 \mathrm{~mL}$ each. The total protein content of the supplement together with that of the consumed regular meals was more than enough to ensure the amount of protein needed for the optimal protein synthesis that is recommended for repletion of malnourished subjects (1.5 to $1.7 \mathrm{~g}$ protein $/ \mathrm{kg}$ body weight/day).

Resting energy expenditure (REE) and dietary intake were assessed at baseline and end of treatment. REE was measured by an open circuit indirect calorimetry system using

Table I Essential amino acid composition

\begin{tabular}{ll}
\hline L-Leucine & $1250 \mathrm{mg}$ \\
L-Lysine & $650 \mathrm{mg}$ \\
L-Isoleucine & $625 \mathrm{mg}$ \\
L-Valine & $625 \mathrm{mg}$ \\
L-Threonine & $350 \mathrm{mg}$ \\
L-Cysteine & $150 \mathrm{mg}$ \\
L-Histidine & $150 \mathrm{mg}$ \\
L-Phenylalanine & $100 \mathrm{mg}$ \\
L-Methionine & $50 \mathrm{mg}$ \\
L-Tyrosine & $30 \mathrm{mg}$ \\
L-Tryptophan & $20 \mathrm{mg}$ \\
B6 vitamin & $0.15 \mathrm{mg}$ \\
BI vitamin & $0.15 \mathrm{mg}$ \\
\hline
\end{tabular}


a ventilated hood. Measurements were started in the early morning (08:00 hours). After an overnight fasting, patients had a period of at least 30 minutes of bed rest prior to the measurements during which subjects were comfortably lying on a bed in a supine position. After stabilization, REE was recorded during a period of 30 minutes and calculated from oxygen consumption and carbon dioxide production using the abbreviated Weir formula:

$$
\operatorname{REE}(\mathrm{kcal} / \mathrm{h})=\left(3.9 \times \mathrm{VO}_{2}+1.1 \times \mathrm{VCO}_{2}\right) \times 1.44 / 24 .
$$

Dietary intake was assessed using a 3-day food diary, by recording everything the patients ate or drank for 3 consecutive days, using household measurements to quantify items. Physical activity performed which lasted $>10$ minutes was also recorded. Apparent discrepancies were checked with the subject. The information was coded for computer nutrient analysis by the same trained dietician. The nutrient database was derived from the IEO food composition database (BDA). ${ }^{12}$ At end of treatment, a dietician reviewed the food diary to ascertain maintenance of actual content and total caloric value.

The inpatient rehabilitation program consisted of general physical training, with particular attention to exercise in relation to daily activities. ${ }^{13}$ Five days a week a combined endurance and strength exercise training was followed, consisting of 30 minutes of submaximal cycle ergometry, and 30 minutes of treadmill walking, and one session of unsupported arm exercise training. The submaximal cycle ergometry was set at $50 \%$ of peak workload and increased during the training progression under the supervision of an exercise therapist. The outpatient program was a 5-day week, self-reported home program.

\section{Body composition}

Body height and weight were measured to calculate body mass index. Possible disturbances in body composition were assessed by dual-energy X-ray absorptiometry (DEXA), which is a direct method of assessing bone mineral content and the soft tissue surrounding the bone: FFM and fat mass (FM). Each patient lying in supine position on a scan table for approximately 15 minutes was scanned by DPX-L Bone Densitometry (Lunar Radiation Corp., Madison, WI, USA). Total and subregional FM and FFM were derived according to the computer algorithm (Lunar software version 1.3; Madison, WI, USA) provided by the manufacturer. The FFM index (FFMI) was calculated as FFM to height-squared ratio. According to previous studies ${ }^{14}$ a low FFMI was classified as a FFMI $\leq 15 \mathrm{~kg} / \mathrm{m}^{2}$ (women) and $\leq 16 \mathrm{~kg} / \mathrm{m}^{2}$ (men).

\section{Lung function, and performance status}

Lung function testing included spirometry $\mathrm{FEV}_{1}$ and FVC, thoracic gas volumes, and carbon monoxide (CO) transfer factor $\left(\mathrm{TL}_{\mathrm{CO}}\right)$, (Masterlab; Jaeger, Wurzurg, Germany). Predicted equations utilized were those of Quanjer et al. ${ }^{15}$ Arterial blood samples were gently drawn from the brachial artery using a dedicated pre-heparinized blood sampler, while patients were seated and breathing room air. Oxygen breathing was temporarily withdrawn for at least 30 minutes in patients under oxygen therapy. Immediately after sample collection, mixing, and removal of the first drops of blood, the acid-base and oxygen status were analyzed. Arterial negative logarithm of hydrogen ion concentration $(\mathrm{pH})$ and arterial carbon dioxide tensions $\left(\mathrm{PaCO}_{2}\right)$, together with arterial oxygen tension $\left(\mathrm{PaO}_{2}\right)$ and the oximetry parameters were measured using a blood gas analyzer (ABL Model 700 System Radiometer, Copenhagen, Denmark). The following oximetry parameters were directly measured: 1) concentration of total hemoglobin in the blood $(\mathrm{tHb})$, which includes all types of hemoglobin ie, oxy- $\left(\mathrm{O}_{2} \mathrm{Hb}\right)$, deoxy- $(\mathrm{HHb})$, carboxy$(\mathrm{COHb})$, and meta-hemoglobin (MetHb); 2) arterial oxygen saturation $\left(\mathrm{sO}_{2}\right)$ (ie, the ratio between the concentration of $\mathrm{O}_{2} \mathrm{Hb}$ and $\mathrm{HHb}+\mathrm{O}_{2} \mathrm{Hb}$ ); 3) fraction of oxyhemoglobin $\left(\mathrm{FO}_{2} \mathrm{Hb}\right)\left(\mathrm{ie}\right.$, the ratio between the concentration of $\mathrm{O}_{2} \mathrm{Hb}$ and $\mathrm{tHb}$ ); 4) fraction of carboxyhemoglobin ( $\mathrm{FCOHb})$ (ie, the ratio between concentration of $\mathrm{COHb}$ and $\mathrm{tHb}$ ); 5) fraction of metahemoglobin (FMetHb) (ie, the ratio between concentration of $\mathrm{MetHb}$ and $\mathrm{tHb})$; 6) total arterial oxygen content $\left(\mathrm{ctO}_{2}\right)$ (ie, the sum of the concentration of hemoglobin-bound oxygen and the concentration of physically dissolved oxygen). The concentration of effective hemoglobin (ceHb), ie, the concentration of total hemoglobin ( $\mathrm{ctHb}$ ) corrected for fractions of carboxyhemoglobin $(\mathrm{FCOHb})$ and metahemoglobin (FMetHb), which are unable to bind oxygen reversibly, was calculated as a measurement of hemoglobin oxygen binding capacity. Both oxygen tension at half saturation $(50 \%)$ of blood $\left(\mathrm{P}_{50}\right)$, and oxygen extraction tension of arterial blood $\left(\mathrm{PaO}_{2 \mathrm{x}}\right)$, were calculated by extrapolation along the shape of the oxygen binding curve on the $\log \mathrm{PaO}_{2}-\mathrm{ctO}_{2}$ diagram, by a dedicated computer program. ${ }^{16}$ The shape of the curve was modeled on the basis of the $\mathrm{PaO}_{2}$ and the hemoglobin oxygen saturation fraction measured in the arterial blood, using a hyperbolic tangent function..$^{10}$ Performance status of the patients was assessed by body-mass index (B), the degree of airflow obstruction (O) and dyspnea (D), and exercise capacity (E) (BODE index). ${ }^{17}$ 


\section{Blood sampling}

Fasting blood samples were collected, early in the morning (08:00 to 10:00 hours). Plasma glucose concentration was determined by glucose oxidative methods (Dimension clinical chemistry system, Dade Behring), using a glucose auto analyzer. Plasma insulin (95\% intra-assay coefficient of variation $\leq 29.1 \mu \mathrm{UI} / \mathrm{mL}$ ) was determined by commercial radio-immuno assay (Immulite 2000, Siemens). C-reactive protein (CRP) was measured in duplicate by high sensitivity turbidimetric immuno-assay (PETIA) (Dade Behring), with a lower detection limit of $0.5 \mathrm{mg} / \mathrm{L}$.

\section{Statistical analysis}

Comparisons between groups were carried out by onefactor ANOVA or Chi-square test if the examined variable was, respectively, continuous or categorical. To test for the effect of EAA supplementation on body weight and FFM, we used a two-factor ANOVA (factors: treatment and time, with repeated measurements in the latter), adjusting for sex. Univariable and multivariable linear regression analysis was used to assess the association between insulin, C-RP blood level and $\mathrm{PaO}_{2 \mathrm{x}}$, (the explanatory variables) and the change in FFM after nutritional intervention (the response variable). Multivariable model building was carried out by a forward selection procedure with 0.50 significance level for entry of variables into the model (Proc. Reg, SAS/STAT-SAS Institute Inc., Cary, NC, USA). Person's correlation coefficient was used to assess the association between continuous variables. All tests were two-tailed and a $P<0.05$ was considered statistically significant. Descriptive statistics are given as mean $( \pm \mathrm{SD})$ or as a percentage value for continuous, and respectively categorical variables.

\section{Results}

Figure 1 details the flow diagram for patients' allocation to the intervention groups.

The majority of patients (96\%) were on maintenance medication consisting of inhaled $\beta_{2}$-agonists, and inhaled corticosteroids therapy; none of them took systemic steroids at the time of the study.

Baseline anthropometrics, smoking habitus, performance status and lung function data in the EAAs and $\mathrm{C}$ groups are reported in Table 2. The two groups were comparable for age, smoking habit and performance status as assessed

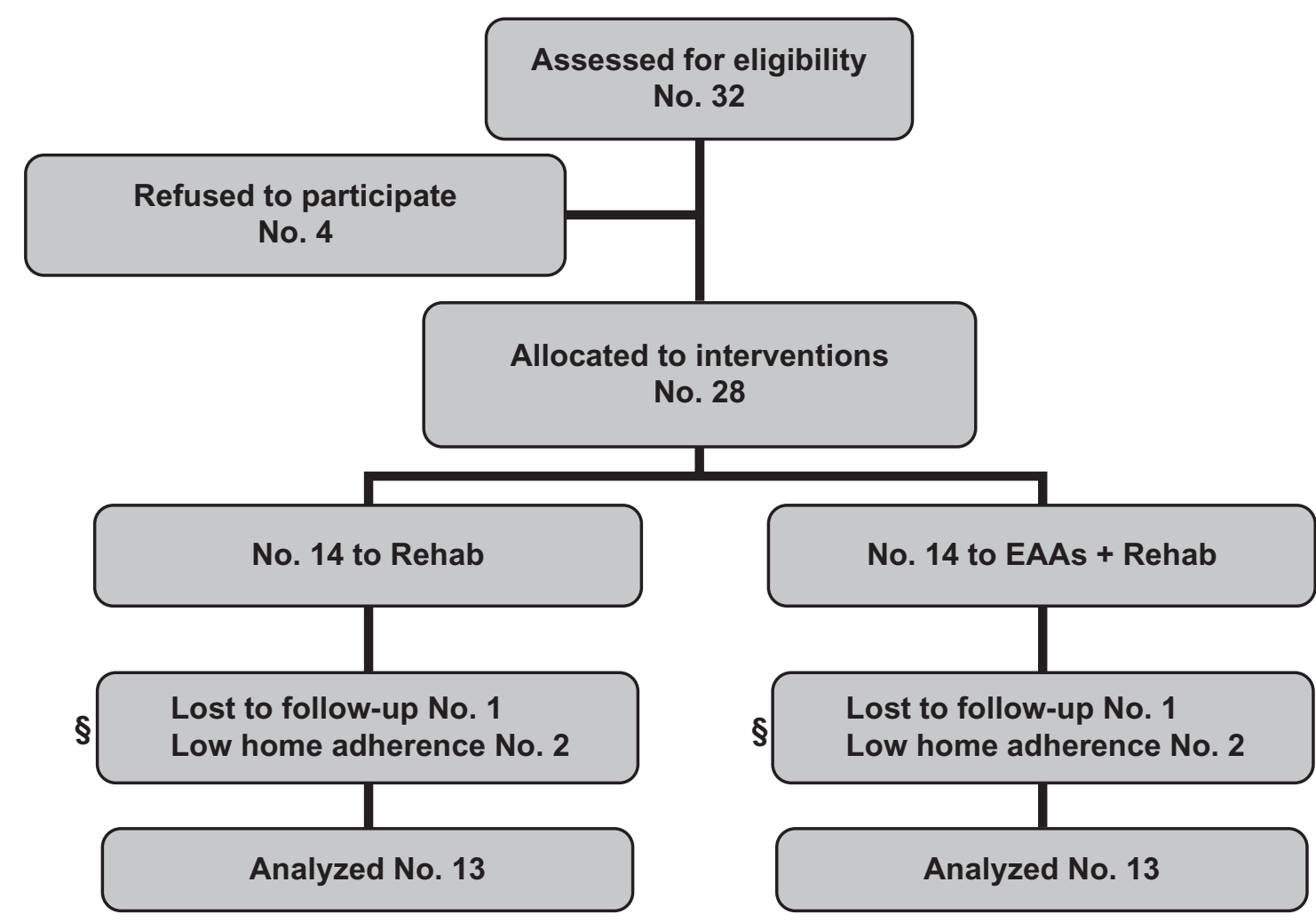

Figure I The flow diagram for patients' allocation to EAAs + rehabilitation and rehabilitation interventions.

$\S$ Number of patients who did not exercise on a regular basis and/or spontaneously reduced the dose of EAA to $4 \mathrm{~g}$ daily.

Abbreviation: EAAs, essential amino acid supplementation. 
by the four domains of the BODE index, and pulmonary functional impairment. A higher number of females were allocated to the $\mathrm{C}$ group. The frequency of patients with long term oxygen therapy was evenly distributed between the groups.

Table 3 reports baseline body composition, dietary intake, resting energy expenditure, oxygen status of arterial blood, and laboratory parameters in both groups. All these variables were comparable in the two groups. In both groups weight loss in the previous 6 months occurred due to hypermetabolism, despite a normal baseline dietary intake, and resulted in FFM depletion in $77 \%$ of patients. The average C-RP mg/L was increased over normal values, while insulin and glucose plasma levels measured in the fasting state were within the normal range in all the patients. In addition, the serum concentrations of creatinine within the normal range indicated a normal kidney function in all the patients.

At the 12th week, the change in dietary intake was $34 \pm$ $92 \mathrm{kcal} / 24 \mathrm{~h}$ in the EAAs group, and $43 \pm 87 \mathrm{kcal} / 24 \mathrm{~h}$ in the $\mathrm{C}$ group $(P=0.80)$; change in resting energy expenditure as a percentage of Harris-Benedict prediction equation, was $-19 \% \pm 17 \%$ in the EAAs group, and $-12 \% \pm 15 \%$ in the $\mathrm{C}$ group $(P=0.28)$. The change in insulin, $\mathrm{C}-\mathrm{RP}$ and $\mathrm{PaO}_{2 \mathrm{x}}$ was, respectively, $-0.9 \pm 4.4 \mu \mathrm{UI} / \mathrm{mL}(P=0.49)$,
$0.2 \pm 3.7 \mathrm{mg} / \mathrm{L}(P=0.83)$ and $-0.3 \pm 2.7 \mathrm{mmHg}(0.73)$ in the EAAs group. In the $\mathrm{C}$ groups these changes were, respectively, $-0.6 \pm 2.1 \mu \mathrm{UI} / \mathrm{mL}(P=0.33), 1.0 \pm 8.7 \mathrm{mg} / \mathrm{L}$ $(P=0.71)$ and $0.9 \pm 2.7 \mathrm{mmHg}(P=0.26)$. The change in glucose blood level was $-0.7 \pm 12.7 \mathrm{mmol} / \mathrm{L}(P=0.85)$ and $4.1 \pm 16.4 \mathrm{mmol} / \mathrm{L}(P=0.39)$ in the EAAs and $\mathrm{C}$ group, respectively.

A body weight increment occurred in 12 out of 13 patients (92\%) in the EAAs group, and in 2 out of $13(15 \%)$ in the $\mathrm{C}$ group. Body weight increased by $3.8 \pm 2.6 \mathrm{~kg}$ in the EAAs group $(P=0.0002)$ and $-0.1 \pm 1.1 \mathrm{~kg}$ in the $\mathrm{C}$ group $(P=0.81)$. The interaction test between the treatment and time factors $(P=0.0001)$ further supported the significance of the different response in the two groups. An FFM increment occurred in 9 out of 13 patients (69\%) in the EAAs group, and in 2 out of $13(15 \%)$ in the $C$ group. FFM increased by $1.5 \pm 2.6 \mathrm{~kg}$ in the EAAs group $(P=0.05)$ and $-0.1 \pm 2.3 \mathrm{~kg}$ in the $\mathrm{C}$ group $(P=0.94)$. The interaction test between the treatment and time factors was borderline significant $(P=0.05)$.

In order to explore the mechanisms that modulate FFM accretion in response to ingestion of amino acids, we assessed the association between the change in FFM and 12th-week insulin plasma level, $\mathrm{C}-\mathrm{RP}$, and $\mathrm{PaO}_{2 \mathrm{x}}$, in the EAAs group.

Table 2 Baseline characteristics of the 28 weight-losing patients with COPD: anthropometrics, smoking habitus, oxygen therapy, performance status and lung function data

\begin{tabular}{|c|c|c|c|c|c|c|}
\hline Characteristics & & EAAs group & & C group & & $P$ value \\
\hline Started/Completed & No & & $14 / 13$ & & $14 / 13$ & \\
\hline Age & years & 73.1 & $(6.0)$ & 70.1 & (5.8) & 0.29 \\
\hline Gender & $M / F$ & 12 & 2 & 8 & 6 & +0.09 \\
\hline Smokers & Current/Ex & 10 & 4 & 9 & 5 & +0.32 \\
\hline Pack-years & No & 71.9 & $(28.5)$ & 47.4 & $(29.8)$ & 0.12 \\
\hline LTOT & $\mathrm{Y} / \mathrm{N}$ & 3 & 11 & 3 & 11 & 0.25 \\
\hline BMI & $\mathrm{kg} / \mathrm{m}^{2}$ & 19.9 & $(2.8)$ & 21.0 & $(3.8)$ & 0.35 \\
\hline $\mathrm{FEV}_{1}$ & $\%$ pred. & 41.3 & $(14.1)$ & 43.6 & $(14.42)$ & 0.89 \\
\hline MMRC-D & points & 3.2 & $(0.8)$ & 3.1 & $(0.7)$ & 0.69 \\
\hline 6MWD & $\mathrm{m}$ & 224.4 & $(153.9)$ & 259.5 & $(120.5)$ & 0.51 \\
\hline BODE & points & 6.6 & $(2.4)$ & 6.2 & (1.9) & 0.82 \\
\hline VC & $\%$ pred & 70.7 & $(13.2)$ & 79.7 & $(8.7)$ & 0.09 \\
\hline $\mathrm{FEV}_{1} / \mathrm{VC}$ & $\%$ & 40.2 & $(14.1)$ & 47.3 & $(13.8)$ & 0.89 \\
\hline TLC & $\%$ pred & 119 & $(10.8)$ & 110.8 & $(23.4)$ & 0.70 \\
\hline RV & $\%$ pred & 165.4 & $(29.3)$ & 178.4 & $(60.1)$ & 0.35 \\
\hline $\mathrm{TL}_{\mathrm{co}}$ & $\%$ pred & 40.5 & $(14.1)$ & 43.3 & $(16.9)$ & 0.63 \\
\hline
\end{tabular}

Note: Baseline statistics are given as means and (SD). tby $\chi^{2}$ test.

Abbreviations: BMI, body mass, index; BODE, degree of airflow obstruction, dyspnea and exercise capacity index; COPD, chronic obstructive pulmonary disease; Pack-years, no. cigarettes/day/20 years of smoking; LTOT, long-term oxygen therapy; FEV ${ }_{1}$, forced expiratory volume in one second; MMRC-D, scores on the Modified Medical Research Council dyspnea scale; $6 \mathrm{MWD}$, distance walked in 6 minutes; $\mathrm{VC}$, slow vital capacity; FEV, $/ \mathrm{VC}$, Tiffeneau index; TLC, total lung capacity; RV residual volume; TL ${ }_{\mathrm{co}}, \mathrm{CO}$ transfer factor. 
Table 3 Baseline characteristics in 28 weight-losing patients with COPD: body composition, dietary intake, resting energy expenditure, oxygen status, and laboratory parameters*

\begin{tabular}{|c|c|c|c|c|c|c|}
\hline Characteristics & & EAAS group & & C group & & $P$ value \\
\hline Started/Completed & No & & $14 / 13$ & & $14 / 13$ & \\
\hline Body weight & $\mathrm{kg}$ & 55.7 & $(8.4)$ & 57.8 & $(9.0)$ & 0.59 \\
\hline FFM & $\mathrm{kg}$ & 42.7 & $(6.1)$ & 39.5 & $(4.8)$ & 0.24 \\
\hline FM & $\mathrm{kg}$ & 11.8 & $(6.6)$ & 14.8 & $(6.1)$ & 0.36 \\
\hline FFMI & $\mathrm{kg} / \mathrm{m}^{2}$ & 15.1 & $(2.0)$ & 15.3 & $(2.0)$ & 0.89 \\
\hline Dietary intake & $\mathrm{kcal} / 24 \mathrm{~h}$ & 1897 & $(406)$ & 1816 & $(308)$ & 0.57 \\
\hline REE & $\mathrm{kcal} / 24 \mathrm{~h}$ & 1319 & $(305)$ & 1282 & $(229)$ & 0.73 \\
\hline REE_HB & $\%$ pred & 146 & $(23)$ & 137 & (I5) & 0.25 \\
\hline $\mathrm{PaCO}_{2}$ & $\mathrm{mmHg}$ & 41.5 & $(6.9)$ & 42.4 & $(6.7)$ & 0.56 \\
\hline $\mathrm{PaO}_{2}$ & $\mathrm{mmHg}$ & 61.5 & $(9.8)$ & 58.3 & $(6.8)$ & 0.46 \\
\hline$P_{50}$ & $\mathrm{mmHg}$ & 24.4 & $(4.2)$ & 23.6 & (1.9) & 0.60 \\
\hline $\mathrm{PaO}_{2 x}$ & $\mathrm{mmHg}$ & 31.0 & $(2.7)$ & 30.2 & $(2.4)$ & 0.44 \\
\hline $\mathrm{tHb}$ & $\mathrm{g} / \mathrm{dL}$ & 13.7 & $(1.9)$ & 14.2 & $(2.2)$ & 0.86 \\
\hline Fasting glucose & $\mathrm{mmol} / \mathrm{L}$ & 5.0 & $(0.6)$ & 4.9 & $(0.7)$ & 0.83 \\
\hline Fasting insulin & $\mu \mathrm{Ul} / \mathrm{ml}$ & 5.5 & $(4.7)$ & 5.2 & $(4.8)$ & 0.89 \\
\hline Albumin & $\mathrm{g} / \mathrm{dL}$ & 3.4 & $(0.7)$ & 3.5 & $(0.5)$ & 0.62 \\
\hline Pre-albumin & $\mathrm{mg} / \mathrm{dL}$ & 21.9 & $(5.6)$ & 26.6 & $(6.2)$ & 0.09 \\
\hline Creatinine & $\mathrm{mg} / \mathrm{dL}$ & 0.9 & $(0.2)$ & 0.9 & $(0.1)$ & 0.59 \\
\hline C-RP & $\mathrm{mg} / \mathrm{L}$ & 9.6 & (7.I) & 12.0 & (7.2) & 0.30 \\
\hline
\end{tabular}

Note: Values are given as means and (SD).

Abbreviations: FFM, fat-free mass; FM, fat mass; FFMI, fat free mass index; REE, resting energy expenditure; REE_HB, resting energy expenditure as a percentage of HarrisBenedict prediction equation; $\mathrm{PaCO}_{2}$, arterial carbon dioxide tension; $\mathrm{PaO}_{2}$, arterial oxygen tension; thb, total hemoglobin; $\mathrm{P}_{50}$, oxygen half saturation tension; $\mathrm{PaO}{ }_{2 \times}$, oxygen extraction tension; C-RP, C-reactive protein.

Univariable linear regression results are shown in Figure 2. To investigate a possible direct effect of glucose blood level on FFM change, we also included in this figure a plot showing the relationship between change in FFM and 12th-week glucose level. A substantial linear association was found between the change in FFM and insulin plasma levels $\left(r^{2}=0.68\right.$, $P<0.001$ - Figure 2, panel A), while a moderate association was found between the change in FFM and both C-RP $\left(\mathrm{r}^{2}=0.46, P<0.01\right.$ - Figure 2, panel $\left.\mathrm{B}\right)$ and $\mathrm{PaO}_{2 \mathrm{x}}\left(\mathrm{r}^{2}=-0.46\right.$, $P<0.01-$ Figure 2, panel C). On the contrary, there was no association change in FFM and fasting glucose plasma levels $\left(r^{2}=0.04, P=0.50\right.$ - Figure 2, panel D). As expected, insulin, C-RP, and $\mathrm{PaO}_{2 \mathrm{x}}$ at the 12th week were mutually highly correlated ( $\mathrm{r}>0.7, P<0.005$ in all tests) (see Table 4).

The multivariable linear regression model included insulin and C-RP, with $\mathrm{p}$ values 0.019 and 0.45 , respectively. This model explained $70 \%$ of the variance of the change in FFM after the rehabilitation program with amino acid supplementation. These results suggest that the predictive information of C-RP is already "contained" in that of the insulin variable, and that $\mathrm{PaO}_{2 \mathrm{x}}$ does not provide any additive information to this two-variable model.
In the $\mathrm{C}$ group there was no significant association between change in FFM and 12th week insulin $\left(\mathrm{r}^{2}: 0.0003, P=0.95-\right.$ Figure 3, panel A), C-RP $\left(\mathrm{r}^{2}: 0.10, P=0.39\right.$ - Figure 3, panel $\mathrm{B})$, and $\mathrm{PaO}_{2 \mathrm{x}}\left(\mathrm{r}^{2}: 0.06, P=0.42\right.$ - Figure 3 , panel $\left.\mathrm{C}\right)$. Furthermore, no association was found between change in FFM and fasting glucose plasma levels $\left(\mathrm{r}^{2}=0.004, P=0.98-\right.$ Figure 3, panel D). As found in the EAAs group, insulin, $\mathrm{C}$-RP and $\mathrm{PaO}_{2 \mathrm{x}}$ at the 12 th week were mutually highly correlated ( $\mathrm{r}>0.77, P<0.005$ in all tests), (see Table 4 ).

\section{Discussion}

Results of this study suggest the potential for EAAs associated with physical training to halt or even reverse lean body mass depletion in hypoxemic COPD patients, who experience dynamic weight loss. Furthermore, the study provides several novel insights on the pathophysiological mechanisms that modulate FFM accretion in this disease condition.

First, the positive association between 12th-week FFM change and insulin plasma levels suggests a specific modulation of insulin actions by the amino acid mixture on signaling to protein metabolism in weight losing COPD patients. Second, the significant association between FFM change 
A

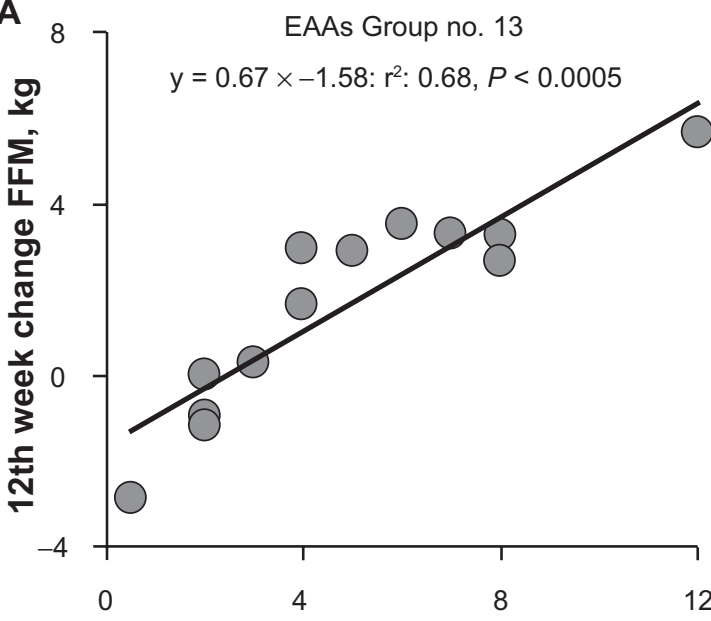

12th week insulin, $\mu \mathrm{Ul} / \mathrm{mL}$

C

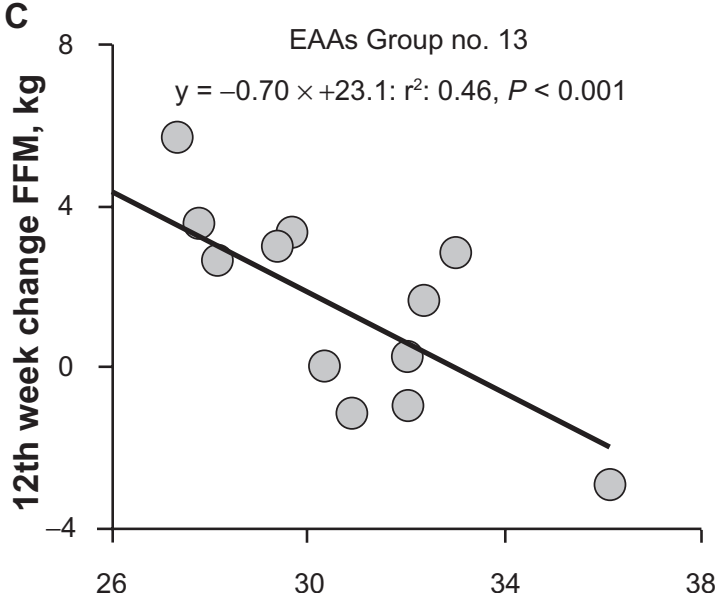

12th week $\mathrm{PaO}_{2 \times}, \mathrm{mmHg}$
B

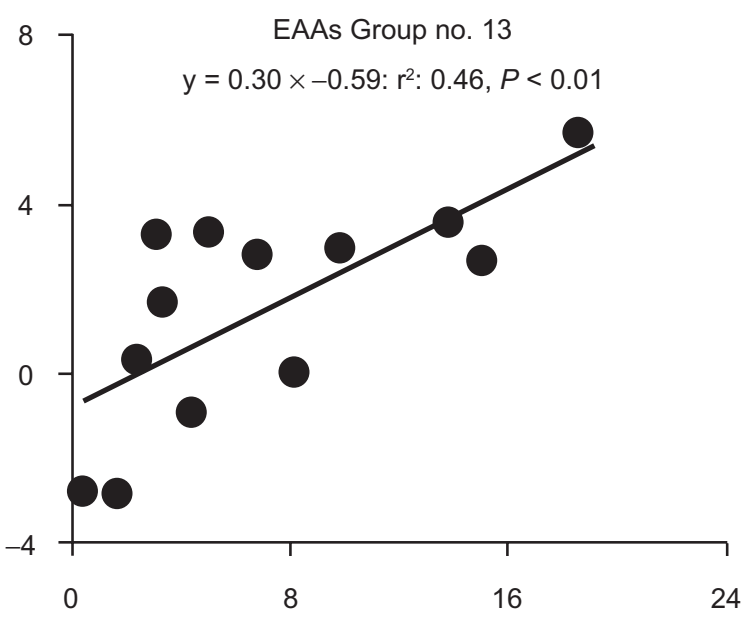

12th week C-RP, mg/L

D

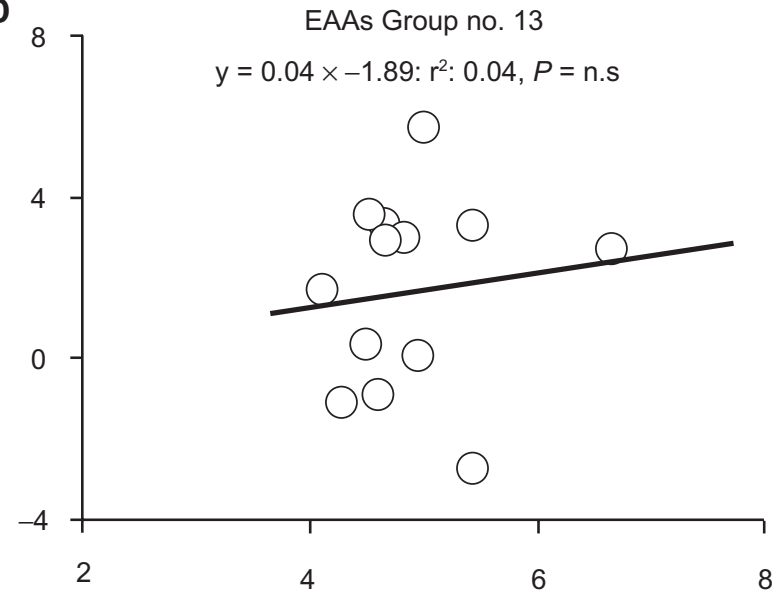

12th week glucose, $\mathrm{mmol} / \mathrm{L}$

Figure 2 Panel A: 12th-week change FFM, as assessed by DEXA, plotted against 12th-week insulin plasma levels, $\mu \mathrm{Ul} / \mathrm{mL}$. Panel B: I2th-week change FFM, plotted against I2th-week C-RP, mg/L. Panel C: I2th-week change FFM, plotted against I2th-week $\mathrm{PaO}_{2 x}, \mathrm{mmHg}$ in I3 patients allocated to EAAs group. Panel D: I2th-week change FFM, plotted against I2th-week glucose plasma levels, mmol/L.

Abbreviations: C-RP, C-reactive protein; DEXA, dual X-ray absorptiometry EAAs, essential amino acid supplementation; $\mathrm{FFM}$, fat-free mass; PaO ${ }_{2 \mathrm{x}}$, oxygen extraction tension.

Table 4 Correlations between insulin, $\mathrm{C}-\mathrm{RP}$, and $\mathrm{PaO}_{2 x}$ in EAAs and $\mathrm{C}$ groups

\begin{tabular}{|c|c|c|c|c|c|}
\hline \multirow[b]{2}{*}{ Group } & & \multicolumn{3}{|c|}{ Baseline measurements } & \multirow[b]{2}{*}{ Group } \\
\hline & & Insulin & C-RP & $\mathrm{PaO}_{2 \mathrm{x}}$ & \\
\hline $\mathrm{E}$ & Insulin & & $0.12(0.73)$ & $-0.39(0.22)$ & $\mathrm{C}$ \\
\hline A & C-RP & $0.03(0.92)$ & & $0.56(0.08)$ & O \\
\hline A & $\mathrm{PaO}_{2 x}$ & $-0.34(0.27)$ & $-0.31(0.32)$ & & $\mathrm{N}$ \\
\hline \multirow[t]{2}{*}{ S } & & & & & $\mathrm{T}$ \\
\hline & & \multicolumn{3}{|c|}{ I 2th-week measurements } & \\
\hline E & Insulin & & $0.77(<0.005)$ & $-0.87(<0.0005)$ & $\mathrm{C}$ \\
\hline A & C-RP & $0.7 \mathrm{I}(<0.0 \mathrm{I})$ & & $-0.89(<0.000 \mathrm{I})$ & O \\
\hline A & $\mathrm{PaO}_{2 x}$ & $-0.80(<0.00 \mathrm{I})$ & $-0.79(<0.005)$ & & $\mathrm{N}$ \\
\hline S & & & & & $\mathrm{T}$ \\
\hline
\end{tabular}

Note: Values are correlation coefficients and $P$ values given in parentheses.

Abbreviations: $\mathrm{C}-\mathrm{RP}, \mathrm{C}$-reactive protein; $\mathrm{PaO}_{2 x}$, oxygen extraction tension; EAAs, essential amino acid supplementation. 
A

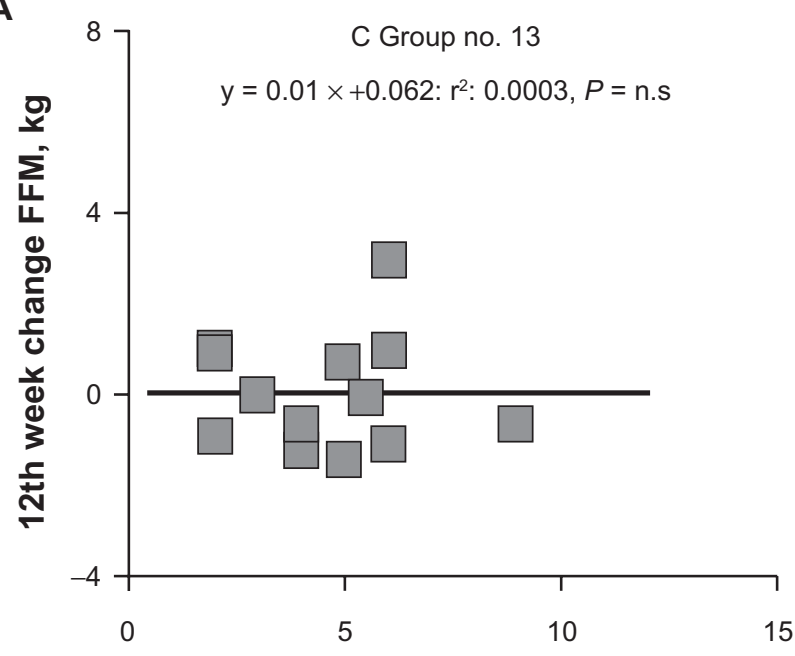

12th week insulin, $\mu U \mathrm{U} / \mathrm{mL}$

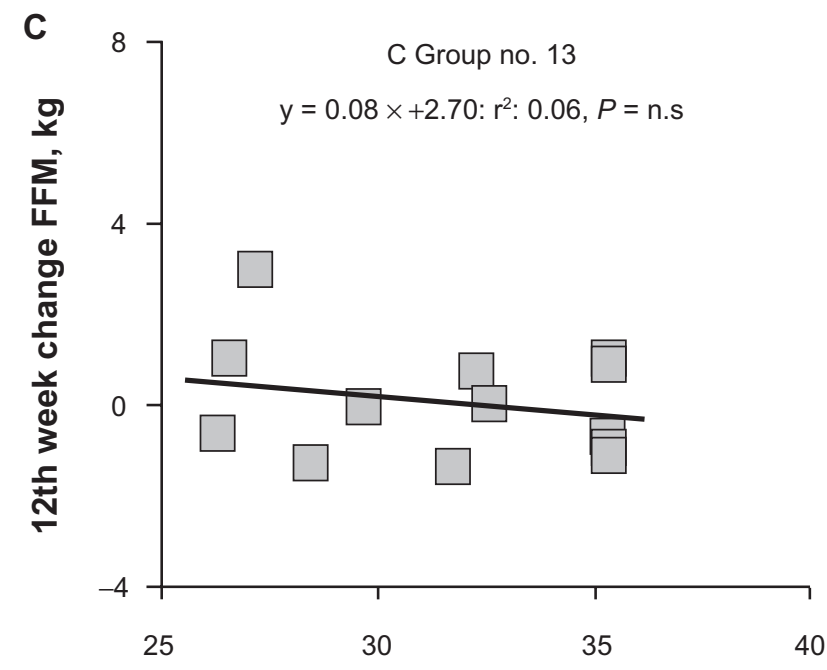

12th week $\mathrm{PaO}_{2 \times}, \mathrm{mmHg}$
B

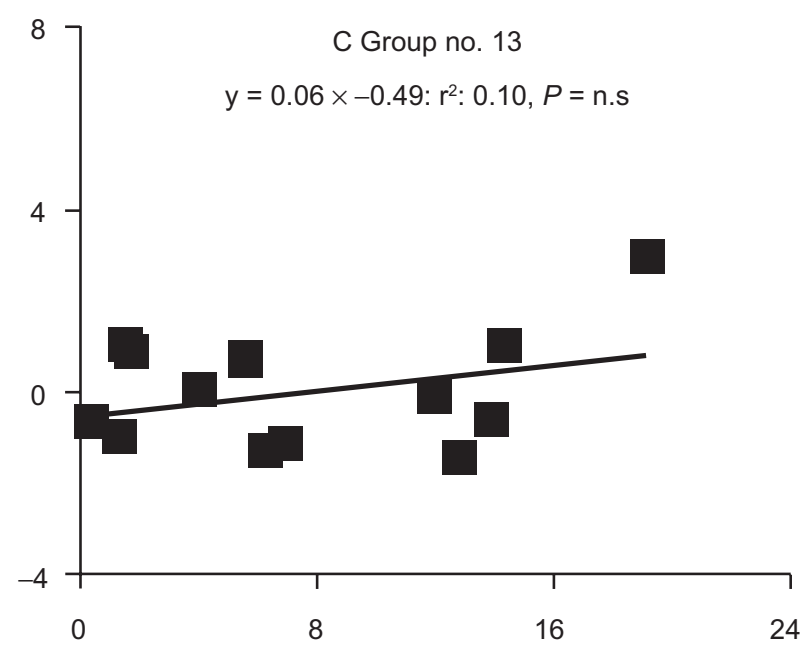

12th week C-RP, mg/L

D

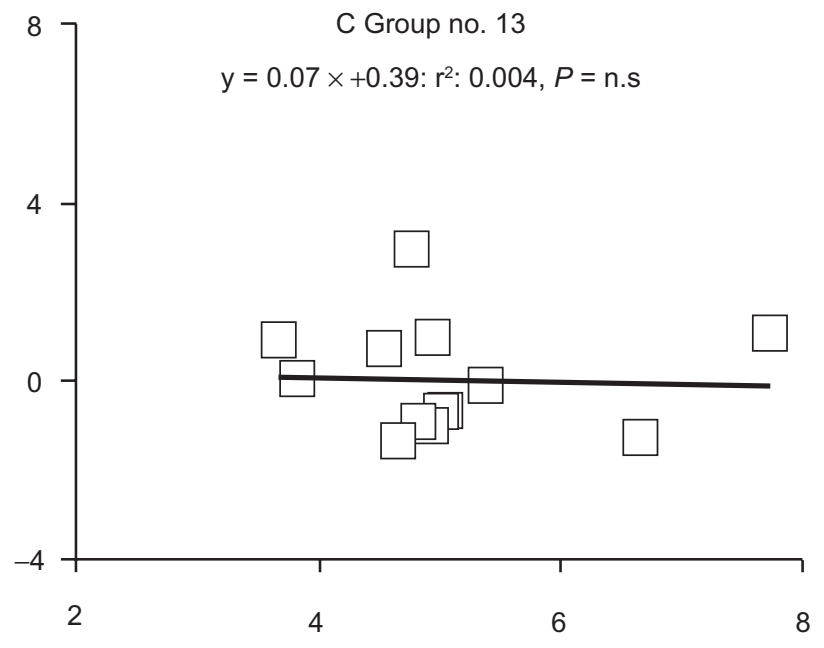

12th week glucose, $\mathrm{mmol} / \mathrm{L}$

Figure 3 Panel A: I2th-week change FFM, as assessed by DEXA, plotted against 12th-week insulin plasma levels, $\mu \mathrm{Ul} / \mathrm{mL}$. Panel B: I2th-week change FFM, plotted against I2th-week C-RP, mg/L. Panel C: I2th-week change FFM, plotted against I2th-week $\mathrm{PaO}_{2 x}$, $\mathrm{mmHg}_{13}$ patients allocated to C Group. Panel D: 12th-week change FFM, plotted against I2th-week glucose plasma levels, $\mathrm{mmol} / \mathrm{L}$.

$P>0.38$ in all tests.

Abbreviations: DEXA, dual X-ray absorptiometry EAAs, essential amino acid supplementation; FFM, fat-free mass; $\mathrm{PaO}_{2 x^{\circ}}$ oxygen extraction tension.

and C-RP blood levels allows some speculation on the involvement of C-RP synthesis pathway in the scenario of downregulation of insulin actions by the amino acid mixture on signaling to glucose metabolism. Third, the mutual relationship between tissue oxygen availability, insulin plasma levels, and C-RP sheds light on the interaction between tissue hypoxia, energy metabolism, and substrate utilization after rehabilitation interventions.

The anabolic effect on FFM after nutritional rehabilitation is consistent with previous metabolic studies on ingestion of proteins, or infusion of mixed amino acids conducted in normal human subjects, ${ }^{18,19}$ and normal-weight COPD patients. ${ }^{20}$ While increased availability of supplemented amino acids or increased cellular level of ATP resulting from their metabolism is supposed to account for this anabolic effect, the notion that branched chain amino acids specifically induce protein synthesis suggests a direct action on signaling to several metabolic pathways.

Several studies have consistently documented lower plasma concentration of branched chain amino acids and reduction in glutamate status in COPD patients compared to control subjects. ${ }^{5,7,8,21,22}$ These differences have been 
specifically associated with weight loss and decreased muscle mass, and respectively with reduced muscle glutathione levels, and enhanced glycolysis during ischemic and hypoxic conditions. ${ }^{8,23}$ To date however, any cross-talk between amino acid and insulin signals as determinant of the switch to FFM accretion remains largely speculative in depleted patients with COPD.

Reportedly, high physiologic concentrations of branchedchain amino acids, particularly leucine, activate intermediates important in the initiation of protein synthesis, including p70 S6 kinase and PHAS-I, in synergy with insulin. Concurrently, amino acids inhibit early steps of insulin action critical for glucose transport and inhibition of gluconeogenesis, including decreased insulin-stimulated tyrosine phosphorylation of IRS-1 and IRS-2, and a marked inhibition of insulinstimulated phosphatidylinositol 3-kinase. ${ }^{9}$ The significant relationship between 12th-week FFM change and 12th-week insulin plasma levels in this study extends this hypothesis to COPD patients, and provides us with a clinical model to explore the amino acid accretion into proteins in relation to insulin signaling pathways. The clinical rehabilitation setting of the study prevents the ability of using sophisticated techniques to ascertain to which extent glucose uptake mechanisms (ie, membrane transport and phosphorylation), and their metabolic regulation may contribute to the amino acid anabolic effect. Nevertheless, the finding that change in FFM bears a strong relationship to insulin plasma levels, and no relationship to glucose plasma levels, further supports the hypothesis of a direct association between insulin and amino acid accretion into proteins. These results seem to be in line with experimental evidence obtained in the ovine fetus that insulin promotes amino acid utilization and oxidation, independent of its simultaneous effects on glucose metabolism. ${ }^{24}$

At first, we were puzzled by the observation that higher FFM gain was associated with higher C-RP blood levels; however, the notion that branched chain amino acids downregulate insulin actions on glucose metabolism in vivo, specifically blunting glycogen synthesis as well as stimulating gluconeogenesis, provides us with a line of reasoning to explain our findings. The association between CRP and IL-6 release induced by exercising muscle is well established..$^{25,26}$ Furthermore, several lines of evidence raise the intriguing possibility that muscle-derived IL-6 has a hormone-like glucoregulatory role, signaling critical low levels of glycogen content, ${ }^{27}$ and stimulating hepatic glucose output. Looking at the correlation between 12th-week C-RP and 12th-week changes in FFM reported in Figure 2B, one may speculate that increased C-RP blood levels in patients showing higher gain of FFM is a marker of IL-6 overproduction in response to impaired insulin action on signaling to glycogen synthesis induced by amino acid supplementation. Alternatively, C-RP may directly contribute to impairment of insulin signaling pathways that promote glucose transport and glycogen synthesis, ${ }^{28}$ while stimulating endogenous glucose production. ${ }^{29}$ Along this line of reasoning, wasting of lean body mass, commonly present in patients with COPD, must be regarded as a complex process involving changes in the control of glucose, as well as of intermediary metabolism that is modulated by nutritional signaling through a variety of different pathways. Among these, hypoxia seems to play a pivotal role in the regulation of metabolic demand of lean body mass. ${ }^{8,23}$ The mutual association between insulin plasma levels, C-RP, and $\mathrm{PaO}_{2 \mathrm{x}}$ suggests an interplay between tissue oxygen availability and sensing and signaling mechanisms to substrate utilization after nutritional rehabilitation.

\section{Limitations of the study}

While measuring the change of FFM by DEXA, a well validated technique for evaluation of body composition, ${ }^{30,31}$ we would rather with this study unravel pathophysiological mechanisms elicited by EAAs under condition of wasting than specifically address the issue of response to nutritional supplementation in COPD. Nevertheless, the prospective changes of body weight and FFM we obtained are far beyond the reported within-day variability of whole body weight. ${ }^{32}$ In comparison to pretrial information provided by randomized controlled trials about the improvements of anthropometric measurements by any caloric supplementation lasting $>2$ weeks $^{33}$ this result is clinically meaningful. However, there are some limitations to this study.

First, it must be stressed that the number of patients allocated to each group was too low to rely on for definitive conclusions about the potential benefit of EAAs. Thus, our preliminary results should be interpreted with caution, as the small number of patients studied may have emphasized the positive effect of treatment on body weight and FFM. Second, the assessor was not blinded to patient allocation, which could have led to bias in evaluating the effect of treatment. The higher number of females in the $\mathrm{C}$ group although not statistically significant likely represents a randomization bias. Third, it was apparent that about $14 \%$ of the participants had some difficulties in adhering to the home-based nutritionrehabilitation intervention. Thus, support, motivation, and a realistic request for commitment should to be considered for future recruitment. Last, although the inability to weigh the 
role of EAAs independent of standardized metabolic load of training may be viewed as a confounding factor in the evaluation of potential benefits of the study, it was unethical to withhold pulmonary rehabilitation in patients who had been proved to benefit of this treatment option.

In summary, the potential for supplemented circulating amino acids in the regulation of insulin mediated signaling to protein and glucose metabolism reconciles the bedside with bench investigations. These results provide us with a rationale for use of EAAs as a valuable adjunct to exercise training programs aimed at stabilizing or even reversing the negative effects of lean body mass wasting in COPD patients.

\section{Acknowledgments}

The authors thank the respiratory pathophysiology staff, and exercise therapists at Montescano Scientific Institute, Fondazione S Maugeri I.R.C.C.S for technical assistance; Mrs Jennifer Chesterfield for English editing assistance.

\section{Disclosures}

The authors report no conflict of interest in this work.

\section{References}

1. Schols AM, Soeters PB, Dingemans AM, Mostert R, Frantzen PJ, Wouter EF. Prevalence and characteristics of nutritional depletion in patients with stable COPD eligible for pulmonary rehabilitation. Am Rev Respir Dis. 1993;147:1151-1156.

2. Vestbo J, Prescott E, Almdal T, et al. Body mass, fat free body mass, and prognosis in patients with chronic obstructive pulmonary disease from a random population sample: findings from the Copenhagen City heart study. Am J Respir Crit Car Med. 2006;173:79-83.

3. Morrison WL, Gibson JNA, Scrimgeour C, Rennie MJ. Muscle wasting in emphysema. Clin Sci. 1988;75:415-420.

4. Engelen MPKJ, Deutz NEP, Wouters EFM, Schols AMWJ. Enhanced levels of whole body protein turnover in patients with chronic obstructive pulmonary disease. Am J Repir Crit Care Med. 2000;162: 1488-1492.

5. Schols AMWJ, Buurman WA, Staal van den Brekel AJ, Dentener MA, Wouters EF. Evidence for a relation between metabolic derangements and increased levels of inflammatory mediators in a subgroup of patients with chronic obstructive pulmonary disease. Thorax. 1996;51: 819-824.

6. Pouw M, Schols AMWJ, Deutz NEP, Wouters EFM. Plasma and muscle amino acid levels in relation to resting energy expenditure and inflammation in stable chronic obstructive pulmonary disease. Am J Respir Crit Care Med. 1998;158:797-801.

7. Hofford JM, Milakofsky L, Vogel WH, Sacher RS, Savage GJ, Pell S. Nutritional status in advanced emphysema associated with chronic bronchitis. A study of amino acid and catecholamine levels. Am Rev Respir Dis. 1990;141:902-908.

8. Wiesner RJ, Deussen A, Borst M, Schrader J, Grieshaber MK. Glutamate degradation in the ischemic dog heart: contribution to anaerobic energy production. J Mol Cell Cardiol. 1989;21:49-59.

9. Patti ME, Brambilla E, Luzi L, Landaker EJ, Kahn CR. Bidirectional modulation of insulin action by amino acids. J Clin Invest. 1998;101: $1519-1529$.
10. Siggaard-Andersen O, Wimberley PD, Gøthgen IH, Siggaard-Andersen M. A mathematical model of the haemoglobin-oxygen dissociation curve of human blood and of the oxygen partial pressure as a function of temperature. Cli Chem. 1984;30:1646-1651.

11. Celli BR, MacNee W. Standards for the diagnosis and treatment of patients with COPD: a summary of the ATS/ERS position paper. Eur Respir J. 2004;23:932-946.

12. Food Composition Database for epidemiological study in Italy by Gnagnarella P, Salvini S, Perpinel M. Version 1.2008. URL: http//: www.ieo.it/bda.

13. Creutzberg EC, Wouters EF, Mastert R, Weling-Scheepers CA, Schols AM. Efficacy of nutritional supplementation therapy in depleted patients with chronic obstructive pulmonary disease. Nutrition. 2003;19: $120-127$.

14. Baarends AM, Schols AMWJ, Mostert R, Wouters E. Peak exercise response in relation to tissue depletion in patients with chronic obstructive pulmonary disease. Eur Respir J. 1997;10:2807-2813.

15. Quanjer PhH, Tammeling GJ, Cotes JE, et al. Standardized lung function testing. Eur Respir J. 1993;6:5-40.

16. Siggard-Andersen M, Siggard-Andersen O. The Oxygen status algorithm: a computer program for calculating and displaying $\mathrm{pH}$, blood gas data. Scand J Clin Lab Invest. 1990;59 Suppl 203:29-45.

17. Celli BR, Cote CG, Marin JM, et al. The body-mass index, airflow obstruction, dyspnea, and exercise capacity index in chronic obstructive pulmonary disease. $N$ Engl J Med. 2004;350:1005-1012.

18. Flakoll PJ, Wentzel LS, Rice DE, Hill JO, Abumrad NM. Short term regulation of insulin-mediated glucose utilization in four-day fasted human volunteers: role of amino acid availability. Diabetologia. 1992;35:357-366.

19. Giordano M, Castellino P, De Fronzo R. Differential responsiveness of protein synthesis and degradation to amino acid availability in humans. Diabetes. 1996;45:393-399.

20. Engelen MP, Rutten EP, De Castro CL, Wouters EFM, Schols AM, Deutz NE. Supplementation of soy protein with branched-chain amino acids alters protein metabolism in healthy elderly and even more in patients with chronic obstructive pulmonary disease. Am J Clin Nutr. 2007;85:431-439.

21. Engelen M, Wouters EFM, Deutz NEP, Menehere PPCA, Schols AMWJ. Factors contributing to alterations in skeletal muscle and plasma amino acid profiles in patients with chronic obstructive pulmonary disease. Am J Clin Nutr. 2000;72:1480-1487.

22. Engelen MPKJ, Schols AMWJ, Does JD, Deutz NEP, Wouters EFM. Altered glutamate metabolism is associated with reduced muscle glutathione levels in patients with emphysema. Am J Respir Crit Care Med. 2000;161:98-103.

23. Engelen MPKJ, Schols AMWJ, Does JD, Gosker HR, Deutz NEP, Wouters EFM. Exercise-induced lactate increase in relation to muscle substrates in patients with chronic obstructive pulmonary disease. Am J Respir Crit Care Med. 2000;162:1697-1704.

24. Brown LD, Hay WW. Effect of hyperinsulinemia on amino acid utilization and oxidation independent of glucose metabolism in the ovine fetus. Am J Physiol Endocrinol Metab. 2006;291:E1333-E1340.

25. Pedersen BK, Hoffman-Goetz L. Exercise and the immune system: regulation, integration, and adaptation. Physiol Rev. 2000;80:1055-1081.

26. Akira S, Taga T, Kishimoto T. Interleukin-6 in biology and medicine. Adv Immunol. 1993;54:1-78.

27. Steensberg A, van Hall G, Osada T, Sacchetti M, Saltin B, Pedersen BK. Production of interleukin 6 in contracting human skeletal muscles can account for the exercise induced increase in plasma IL-6. J Physiol. 2000; 29:237-242.

28. D’Alessandris C, Lauro R, Presta I, Sesti G. C-reactive protein induces phosphorylation of insulin receptor substrate- 1 on $\mathrm{Ser}^{307}$ and $\mathrm{Ser}^{612}$ in L6 myocytes, thereby impairing the insulin signalling pathway that promotes glucose transport. Diabetologia. 2007;50:840-849.

29. Birjmohun RS, Bisoendial RJ, van Leuven SI, et al. A single bolus infusion of C-reactive protein increases gluconeogenesis and plasma glucose concentration in humans. Metabolism. 2007;56:1576-1582. 
30. Mazess RBH, Barden J, Bisek P, Hanson J. Dual-energy X-ray absorptiometry for total body and regional bone-mineral, and soft tissue composition. Am J Clin Nutr. 1990;51:1106-1112.

31. Steinert MC, Barton RL, Singh SJ, Morgan MD. Bedside methods versus dual energy X-ray absorptiometry for body composition measurement in COPD. Eur Respir J. 2002;19:626-631.
32. Cheuvront SN, Carter R3d, Montain SJ, Sawka MN. Daily body mass variability and stability in active man undergoing exercise-heat stress. Int J Sport Nutr Exerc Metab. 2004;14:532-540.

33. Ferreira IM, Brooks D, Lacasse Y, Goldstein RS. Nutritional support for individual with COPD. Chest. 2000;117:672-678.

International Journal of COPD

\section{Publish your work in this journal}

The International Journal of COPD is an international, peer-reviewed journal of therapeutics and pharmacology focusing on concise rapid reporting of clinical studies and reviews in COPD. Special focus is given to the pathophysiological processes underlying the disease, intervention programs, patient focused education, and self management protocols.

\section{Dovepress}

This journal is indexed on PubMed Central, MedLine and CAS. The manuscript management system is completely online and includes a very quick and fair peer-review system, which is all easy to use. Visit $\mathrm{http}: / /$ www.dovepress.com/testimonials.php to read real quotes from published authors.

Submit your manuscript here: http://www.dovepress.com/international-journal-of-copd-journal 